\title{
Thermodynamic Constraints on Electromicrobial Protein Production
}

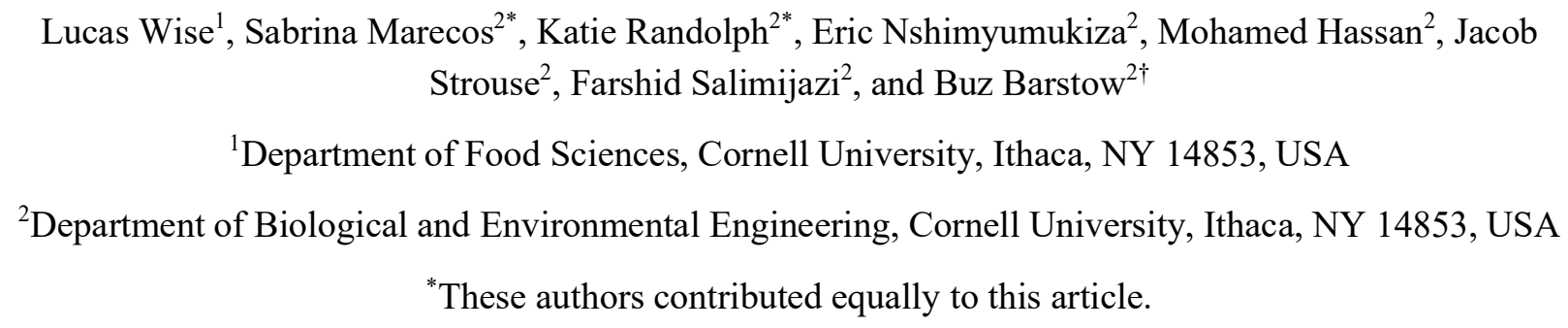

$\uparrow$ Corresponding author:

Buz Barstow, 228 Riley-Robb Hall, Cornell University, Ithaca, NY 14853; bmb35@cornell.edu

\section{Abstract}

12 Global consumption of protein is projected to double by the middle of the $21^{\text {st }}$ century ${ }^{1}$. However, protein 13 production is one of the most energy intensive and environmentally damaging parts of the food supply 14 system today. Electromicrobial production technologies that combine renewable electricity and $\mathrm{CO}_{2}$-fixing 15 microbial metabolism could dramatically increase the energy efficiency of commodity chemical 16 production $^{2-5}$. Here we present a molecular-scale model that sets an upper limit on the performance of any 17 organism performing electromicrobial protein production. We show that engineered microbes that fix $\mathrm{CO}_{2}$ 18 and $\mathrm{N}_{2}$ using reducing equivalents produced by $\mathrm{H}_{2}$-oxidation or extracellular electron uptake could produce amino acids with energy inputs as low as $64 \mathrm{MJ} \mathrm{kg}^{-1}$. This work provides a roadmap for development of engineered microbes that could significantly expand access to proteins produced with a low environmental

21 footprint.

\section{Introduction}

\section{Current methods of protein production are environmentally damaging}

24 Current food consumption and farming practices produce a large amount of environmental strain. In particular, the production of livestock for protein leads to significant waste accumulation and energy expenditure $^{6}$. The agricultural and food production sectors are responsible for $\approx 30 \%$ of greenhouse gas emissions, while livestock farming alone accounts for $18 \%$ of emissions ${ }^{7}$. Furthermore, the agricultural industry is responsible for $70 \%$ of total freshwater consumption ${ }^{8} .42 \%$ of freshwater consumption is attributed to livestock production alone ${ }^{8}$. But, increased consumption of protein is one of the best ways to improve human, particularly infant, health and productivity in many parts of the world today ${ }^{9}$.

The energy and water consumption of livestock farming will only increase as global appetites increase. First, population will grow to $\approx 11$ billion by $2050^{10}$. Second, the consumption of food, particularly protein, by each individual will also grow thanks to an expected average annual economic growth rate of $3 \%$ from

342014 to $2050^{11,12}$. Supplying this increased demand while maintaining the current agricultural areal footprint 35 is expected to require a $75 \%$ increase in agricultural productivity ${ }^{10}$. 
Should agricultural production efficiencies remain stagnant, satisfying the food demands of the world's growing and increasingly wealthy population with protein will require massive deforestation ${ }^{13,14}$. Deforestation could eradicate thousands of species and produce large quantities of greenhouse gases, leading to temperature increases exceeding the $2{ }^{\circ} \mathrm{C}$ warming threshold established by the Paris Climate Agreement, even when ignoring emissions from all other human activity ${ }^{15}$.

Incremental improvements in current food production technologies may not meet future demand and sustainability goals. Current approaches to increasing protein production include advanced livestock breeding, and substitution of livestock protein for insect- and plant-based substitutes. However, all of these approaches depend upon increases in crop yields. But, 78\% of the world's land has natural limitations for agricultural development ${ }^{10}$, and significant doubts remain about the possibility of increasing crop yields by mid-century ${ }^{11,16,17}$. Furthermore, increasing water scarcity due to climate change could even depress crop yields in the decades ahead ${ }^{16}$.

\section{Autotrophic metabolism could increase the efficiency of protein production}

Autotrophic microbial production of protein is a promising alternative strategy to conventional food production $^{5,18-20}$. In this class of schemes, externally supplied reducing equivalents are used to power microbial $\mathrm{N}_{2}$ and $\mathrm{CO}_{2}$-fixing metabolism and synthesis of protein molecules ${ }^{21,22}$.

In most systems studied to date, reducing equivalents are supplied by $\mathrm{H}_{2}{ }^{-}$or methane-oxidation. $\mathrm{CO}_{2}-$ fixation is performed by Calvin-Benson-Bassham cycle, the reverse Krebs cycle or the Wood-Ljungdahl 54 pathway.

Autotrophically produced protein has at least three important advantages over traditional protein production methods. First, autotrophic microorganisms can already produce protein at much higher rates than traditional protein sources ${ }^{18,19}$. Secondly, autotrophic protein production does not depend on the availability of arable land and can be run in a closed system. This greatly reduces water and land consumption and inhibits nitrogen runoff to surrounding environments ${ }^{19,23}$. Finally, autotrophic microorganisms can use atmospheric $\mathrm{N}_{2}$ as a substrate, eliminating the need for thermochemical $\mathrm{N}_{2}$-fixation ${ }^{18,19}$.

The cost of autotrophic protein production is dropping rapidly. The cost of production of a single protein has reduced from $\$ 1 \times 10^{6} \mathrm{~kg}^{-1}$ in 2000 to $\approx \$ 100 \mathrm{~kg}^{-1}$ in $2019^{24}$. It is projected that the cost of production of a single protein could drop to below $\$ 10 \mathrm{~kg}^{-1}$ by 2025 , thereby achieving price parity with animal-based protein products $^{24}$.

Theoretical analysis suggests that autotrophic protein production could far exceed the efficiency of plantbased protein. Recent analyses of the performance of electromicrobial production of biofuels ${ }^{2,4}$, where electrically-supplied reducing equivalents are used to power $\mathrm{CO}_{2}$ fixation or formic acid assimilation and biofuel, show that these types of schemes could dramatically exceed the efficiency of photosynthetic biofuel production. These results imply that if $\mathrm{N}_{2}$ fixation were added to these systems, proteins could also be produced at efficiencies exceeding that of photosynthesis. Recent results by Leger et al. ${ }^{5}$ suggest photovoltaic-driven electromicrobial production (EMP) of protein could exceed efficiency of real-world photosynthetic production of protein by at least 2 orders of magnitude.

73 However, up until now, very few attempts have been made at calculating the upper limit efficiency of EMP

74 amino acid or protein production. This paper presents a model and analyzes the theoretical maximum 
energetic efficiency for a system of autotrophic microorganisms, fixing $\mathrm{CO}_{2}$ and $\mathrm{N}_{2}$ using electrons delivered by either extracellular electron uptake $(\mathrm{EEU})^{25}$ or by $\mathrm{H}_{2}$-oxidation ${ }^{26}$. These calculations do not predict the performance of any naturally-occurring organism, but do predict an upper limit efficiency for any natural or synthetic organism using these reactions.

\section{Theory, Results and Discussion}

\section{Theory}

82 We extended our theoretical framework for calculating the efficiency of electromicrobial production(EMP) of biofuels to calculate the efficiency of amino acid production from electrons, $\mathrm{CO}_{2}$ and $\mathrm{N}_{2}$ (ref. ${ }^{4}$ ). A full set of model parameters and associated values used in this article are shown in Table 1, and a full set of symbols for this article are shown in Table S1.

We consider a bio-electrochemical system used to deliver electrons to microbial metabolism (Figures 1A and 1B). Electrical power is used to generate amino acid (or protein) molecules with an energy per molecule $E_{\text {protein }}$ at a rate $\dot{N}_{\text {protein. }}$ Even though this article strictly considers amino acid synthesis, this can be considered equivalent to protein production from an energetic standpoint as no energy is expended in forming the peptide bond needed to polymerize amino acids. We choose to use the subscript protein rather than AA to avoid confusion with the Avogadro constant, $N_{\mathrm{A}}$. Energy per molecule and molecular weight for each amino acid are shown in Table $\mathbf{S 2}$.

The energy conversion efficiency of the system from electricity to amino acids (or protein) is calculated from the ratio of the amount of chemical energy stored per second ( $\left.\dot{N}_{\text {protein }} E_{\text {protein }}\right)$, relative to the power input to the system, $P_{\mathrm{e} \text {, total }}\left(\right.$ ref. $^{4}$ ),

$$
\eta_{E P}=\dot{N}_{\text {protein }} E_{\text {protein }} / P_{e, \text { total }}
$$

The amount of electricity needed to produce a unit-mass of the protein is,

$$
C_{E P}=P_{e, \text { total }} N_{A} /\left(\dot{N}_{\text {protein }} M_{\text {protein }}\right)
$$

where $M_{\text {protein }}$ is the molecular weight of the protein molecule.

100 For a single bio-electrochemical cell system where $\mathrm{CO}_{2}$ - and $\mathrm{N}_{2}$ - fixation are performed in vivo (Figure

101 1A), the upper limit electrical to chemical conversion efficiency of the system is set by the energy density

102 of an amino acid molecule relative to the amount of charge needed to synthesize it from $\mathrm{CO}_{2}$ and $\mathrm{N}_{2}$ (the

103 fundamental charge, $e$, multiplied by the number of electrons needed for synthesis, $v_{\mathrm{ep}}$ ) and the potential

104 difference across the bio-electrochemical cell, $\Delta U_{\text {cell, }}$

$$
\eta_{E P} \leq E_{\text {protein }} /\left(e v_{e p} \Delta U_{c e l l}\right) \text {. }
$$

Thus, the amount of electricity needed to produce a unit-mass of the protein is,

$$
C_{E P} \geq N_{A} \Delta U_{c e l l} e v_{e p} / M_{\text {protein }}
$$

108 For systems where $\mathrm{CO}_{2}$ reduction is performed electrochemically, and the resulting reduction product 109 (typically a $\mathrm{C}_{1}$ compound like formic acid) (refs. ${ }^{27-29}$ ) is further reduced enzymatically (Figure 1B), $v_{\mathrm{ep}}$ is 
substituted for number of electrons needed to convert the $\mathrm{C}_{1}$ product into the final protein product, $v_{\mathrm{e}}$, add 111 (ref. $^{4}$ ),

$$
\eta_{E P} \leq \frac{E_{\text {protein }} \xi_{I 2}}{e v_{e, a d d}\left(\Delta U_{\text {cell } 1}\left(\frac{v_{r} v_{e r} v_{C r} \xi_{I 2}}{\xi_{I 1} \xi_{C} v_{e, a d d}}\right)+\Delta U_{c e l l 2}\right)}
$$

113 where $v_{\mathrm{r}}$ is the number of primary reduction products (i.e., formic acid molecules) needed to synthesize a 114 molecule of the final product, $v_{\text {er }}$ is the number of electrons needed to reduce $\mathrm{CO}_{2}$ to a primary reduction 115 product (i.e., 2 in the case of formic acid), $v_{\mathrm{Cr}}$ is the number of carbon atoms per primary fixation product 116 (i.e., 1 in the case of formic acid), $\xi_{12}$ is the Faradaic efficiency of the bio-electrochemical cell, $\xi_{11}$ is the 117 Faradaic efficiency of the primary abiotic cell $1, \xi_{\mathrm{C}}$ is the carbon transfer efficiency from cell 1 to cell 2.

118 Thus, the amount of electricity needed to produce a unit-mass of the protein when using electrochemical $119 \mathrm{CO}_{2}$-reduction is,

$$
C_{E P} \geq \frac{e v_{e, a d d} N_{A}\left(\Delta U_{c e l l 1}\left(\frac{v_{r} v_{e r} v_{C r} \xi_{I 2}}{\xi_{I 1} \xi_{C} v_{e, a d d}}\right)+\Delta U_{c e l l 2}\right)}{E_{\text {protein }} \xi_{I 2}} .
$$

We calculate the electron requirements, $v_{\mathrm{ep}}$ or $v_{\mathrm{e}}$, add, for amino acid (or protein) synthesis from the number of NAD $(\mathrm{P}) \mathrm{H}\left(v_{\mathrm{p}, \mathrm{NADH}}\right)$ reduced Ferredoxin $\left(\mathrm{Fd}_{\mathrm{red}} ; v_{\mathrm{p}, \mathrm{Fd}}\right)$ and ATP $\left(v_{\mathrm{p}, \mathrm{ATP}}\right)$ molecules needed for the synthesis of the molecule, along with a model of the mechanism used for electron delivery to the microbe ${ }^{4}$.

124 For systems that rely upon $\mathrm{H}_{2}$-oxidation for electron delivery like the Bionic Leaf ${ }^{4,26,30}$ (Figure 1C part 1),

$$
v_{e p, H_{2}}=2 v_{p, N A D H}+2 v_{p, F d}+v_{p, A T P} \frac{\operatorname{ceil}\left(\Delta G_{A T P / A D P} / e \Delta U_{\text {membrane }}\right)}{\text { floor }\left(\left(U_{H_{2}}-U_{\text {acceptor }}\right) / \Delta U_{\text {membrane }}\right)},
$$

where $\Delta G_{\mathrm{ATP} / \mathrm{ADP}}$ is the free energy required for regeneration of ATP, $\Delta U_{\text {membrane }}$ is the potential difference across the cell's inner membrane due to the proton gradient, $U_{\mathrm{H} 2}$ is the standard potential of proton reduction to $\mathrm{H}_{2}, U_{\text {acceptor }}$ is the standard potential of terminal electron acceptor reduction (typically $\mathrm{O}_{2}+2 e^{-}$to $\mathrm{H}_{2} \mathrm{O}$ ), the ceil function rounds up the nearest integer, and the floor function rounds down to the nearest integer.

130 The inner membrane potential difference, $\Delta U_{\text {membrane, }}$ is the largest source of uncertainty in this calculation. 131 Therefore, we present a range of efficiency estimates in Figures $\mathbf{2}$ and $\mathbf{3}$ and throughout the text for $132 \Delta U_{\text {membrane }}=80 \mathrm{mV}$ (BioNumber ID (BNID) $10408284^{31}$ ) to $270 \mathrm{mV}$ (BNID 107135), with a central value 133 of $140 \mathrm{mV}$ (BNIDs 109774, 103386, and 109775).

134 For systems that rely upon EEU for electron delivery like Shewanella oneidensis ${ }^{4,25}$ (Figure 1C part 2),

$$
\begin{gathered}
v_{e p, E E U}=2 v_{p, N A D H}+2 v_{p, F d} \\
+v_{p, A T P} \frac{\operatorname{ceil}\left(\Delta G_{A T P / A D P} / e \Delta U_{\text {membrane }}\right)}{\text { floor }\left(\left(U_{Q}-U_{\text {acceptor }}\right) / \Delta U_{\text {membrane }}\right)} \\
+v_{p, N A D H} \frac{\operatorname{ceil}\left(\left(U_{N A D H}-U_{Q}\right) / \Delta U_{\text {membrane }}\right)}{\text { floor }\left(\left(U_{Q}-U_{\text {acceptor }}\right) / \Delta U_{\text {membrane }}\right)} \\
+v_{p, F d} \frac{\operatorname{ceil}\left(\left(U_{F d}-U_{Q}\right) / \Delta U_{\text {membrane }}\right)}{\text { floor }\left(\left(U_{Q}-U_{\text {acceptor }}\right) / \Delta U_{\text {membrane }}\right)},
\end{gathered}
$$


139 where $U_{\mathrm{Q}}$ is the redox potential of the inner membrane electron carrier, thought to be ubiquinone ${ }^{32}, U_{\mathrm{NADH}}$ 140 is the standard potential of $\mathrm{NAD}(\mathrm{P}) \mathrm{H}$, and $U_{\mathrm{Fd}}$ is the standard potential of Ferredoxin.

141 The $\mathrm{NAD}(\mathrm{P}) \mathrm{H}, \mathrm{ATP}$ and $\mathrm{Fd}_{\mathrm{red}}$ requirements for amino acid synthesis were calculated by balancing networks 142 of reactions for the autotrophic synthesis of the molecule from $\mathrm{N}_{2}$ and $\mathrm{CO}_{2}$ or $\mathrm{N}_{2}$ and formate $\left(\mathrm{COOH}^{-}\right)$. 143 We enumerated all reaction steps for the production of 19 of the 20 dietary amino acids from acetyl-CoA 144 and $\mathrm{NH}_{4}$ using data from the KEGG database in Dataset $\mathbf{S 3}$ (refs. ${ }^{33-35}$ ). Synthesis of histidine was excluded 145 from these calculations because of technical challenges with stoichiometric balancing due to its inseparable 146 connection with purine synthesis. As a comparison point, and to validate our approach, we also consider 147 the synthesis of glucose.

148 Amino acid synthesis reactions were complemented with reactions for $\mathrm{CO}_{2}$-fixation, $\mathrm{C}_{1}$-assimilation, and $149 \quad \mathrm{~N}_{2}$ fixation (Table S3). For this article we considered 6 scenarios in which $\mathrm{CO}_{2}$ was fixed by the well150 known Calvin cycle ${ }^{36}$, the Reductive Tricarboxylic Acid cycle ${ }^{37,38}$, Wood-Ljungdahl (WL) Pathway ${ }^{36}$; the 151 3-hydroxypropionate/4-hydroxybutyrate (3HP-4HB) Pathway ${ }^{38,39}$; 3-hydroxypropionate (3HP) Cycle ${ }^{40}$; 152 and the Dicarboxylate/4-hydroxybutyrate (4HB) $\mathrm{Cycle}^{41}$. In addition, we also considered the artificial 153 Formolase formate assimilation pathway ${ }^{42}$. Finally, in all scenarios, $\mathrm{N}_{2}$ was fixed into metabolism by the 154 iron-molybdenum (FeMo) nitrogenase (Kyoto Encyclopaedia of Genes and Genomes (KEGG) reaction 155 R05185 (refs. 22-24).

156 The overall stoichiometry of autotrophic amino acid synthesis was calculated by a custom flux balance 157 code. Amino acid synthesis reactions (Dataset S1) were combined automatically with the $\mathrm{CO}_{2}$-fixation, $158 \mathrm{C}_{1}$-assimilation, and $\mathrm{N}_{2}$ fixation reactions (Table $\mathbf{S 3}$ ) by a custom code ${ }^{43}$ into a set of stoichiometric 159 matrices, $\mathbf{S}_{\mathbf{p}}$, for each reaction network.

160 Each automatically generated stoichiometric matrix was balanced with a custom flux balance program ${ }^{43}$ to 161 find the overall number of $\mathrm{NAD}(\mathrm{P}) \mathrm{H}, \mathrm{Fd}_{\mathrm{red}}$, and ATP needed for synthesis of each amino acid using each $162 \mathrm{CO}_{2}$-fixation or $\mathrm{C}_{1}$-assimilation pathway.

163 We consider a species number rate of change vector, $\dot{\boldsymbol{n}}$, that encodes the rate of change of number of the 164 reactant molecules over a single cycle of the reaction network; a stoichiometric matrix $\mathbf{S}_{\mathbf{p}}$ that encodes the 165 number of reactants made or consumed in every reaction in the network; and a flux vector $\boldsymbol{v}$ that encodes 166 the number of times each reaction is used in the network. Reactant molecules are denoted as inputs (e.g., $167 \mathrm{CO}_{2}, \mathrm{~N}_{2}, \mathrm{COOH}^{-}$, ATP, $\left.\mathrm{NAD}(\mathrm{P}) \mathrm{H}\right)$, outputs (e.g., $\mathrm{H}_{2} \mathrm{O}$ ), intermediates, or the target molecule (e.g., the 168 amino acid to be synthesized). For the purposes of this thermodynamic analysis, we consider NADH and 169 NADPH to be equivalent as they have near identical redox potentials.

170 The reactant number vector elements for the inputs were calculated by numerically solving the flux balance 171 equation,

$$
\dot{n}=S_{p} v
$$

173 under the constraint that number of each intermediate does not change over a reaction cycle, and that 174 number of target molecules increases by 1 ,

$$
\dot{n}_{i}=\left\{\begin{array}{rr}
0 & \text { if species } i \text { is an intermediate } \\
1 & \text { if species } \text { is the target }
\end{array}\right.
$$


The balanced overall stoichiometry for synthesis of each amino acid is shown in Dataset S2.

177 The number of electrons needed to synthesize an average amino acid was found by calculating the average number of $\mathrm{NAD}(\mathrm{P}) \mathrm{H}, \mathrm{Fd}_{\mathrm{red}}$, and ATP needed for synthesizing 19 of the 20 amino acids.

\section{Results and Discussion}

\section{Electromicrobial Production of Amino Acids and Protein}

182 The electrical and solar energy to protein conversion efficiency ( $\eta_{\mathrm{EP}}$ and $\left.\eta_{S \mathrm{P}}\right)$ and the electrical energy consumption per unit mass $\left(C_{\mathrm{EP}}\right)$ and cost of solar electricity per unit mass $\left(C_{\mathrm{SP}}\right)$ for the production of 19 amino acids was calculated for electron uptake by $\mathrm{H}_{2}$ transport and oxidation and EEU, and $\mathrm{CO}_{2}$ fixation by the Calvin cycle (Figure 2).

Amino acid synthesis has a lower conversion efficiency than purely carbon-containing products due to the high $\mathrm{Fd}_{\mathrm{red}}$ and ATP requirements of $\mathrm{N}_{2}$-fixation (Dataset S1). Despite this, the conversion efficiency either matches, and in most cases exceeds the theoretical maximum conversion efficiency of sunlight to carbohydrate biomass by $\mathrm{C}_{3}$ photosynthesis (Figure 2A). However, Arg, Asn, Gly, and Pro synthesis by $\mathrm{H}_{2}$ and EEU, and Gln synthesis by EEU have lower conversion efficiencies than $\mathrm{C}_{4}$ carbohydrate photosynthesis $^{44,45}$. Synthesis of Cys, Ile, Leu, Met, Phe, Tyr and Val exceed the theoretical efficiency of algal photosynthesis ${ }^{46}$. The average $\mathrm{CO}_{2}, \mathrm{~N}_{2}$, and electricity conversion efficiency for an average amino acid using the Calvin cycle is $25.2_{-3.2}^{+0.5} \%$ when using $\mathrm{H}_{2}$-oxidation, and $23.1_{-3.3}^{+1.0} \%$ when using EEU (Figure 3A).

The electrical energy costs $\left(C_{\mathrm{EP}}\right)$ for individual amino acids using $\mathrm{H}_{2}$-oxidation an the Calvin cycle range from $40.6_{-5.8}^{+0.8} \mathrm{kJg}^{-1}$ for Asp to $88.2_{-14.1}^{+1.9} \mathrm{kJg}^{-1}$ for Arg (Figure 2B). Synthesizing the amino acids by EEU rather than $\mathrm{H}_{2}$ adds between $\approx 5$ and $10 \mathrm{~kJ} \mathrm{~g}^{-1}$. At projected 2030 prices for solar photovoltaic electricity from the DOE's SunShot program of $3 \propto$ per $\mathrm{kWh}^{47}$, this corresponds to a minimum cost of 0.033 $\notin \mathrm{g}^{-1}$ to $0.081 \notin \mathrm{g}^{-1}$ (Figure 2B). The average amino acid synthesis energy cost using $\mathrm{H}_{2}$-oxidation and the Calvin cycle is $67.9_{-9.8}^{+1.3} \mathrm{~kJ}^{-1}$ (Figure 3B).

As noted before, the energy conversion efficiency of systems using EEU is consistently a few percentage points lower than for systems using $\mathrm{H}_{2}$ oxidation ${ }^{4}$ (Figure 2A). In EEU based systems there is a higher electron requirement, and hence cell current, needed for regeneration of $\mathrm{NAD}(\mathrm{P}) \mathrm{H}, \mathrm{Fd}_{\mathrm{red}}$ and $\mathrm{ATP}$. Practically, this is almost offset by a lower minimum cell voltage, resulting in a slightly lower conversion efficiency ${ }^{4}$. Averaged across all amino acids, the efficiency of synthesis for systems using EEU and the Calvin cycle is $23.1_{-3.3}^{+1.0} \%$. This results in an average electrical energy cost that of $74.1_{-12.5}^{+3.1} \mathrm{~kJ} \mathrm{~g}^{-1}$, about $6 \mathrm{kJg}^{-1}$ higher than the cost of synthesis using $\mathrm{H}_{2}$-oxidation.

Can we use biological engineering to increase the energetic efficiency of electromicrobial production of amino acids? As we have examined before ${ }^{4}$, we can improve efficiency by swapping the Calvin cycle for the an alternative $\mathrm{CO}_{2}$ fixation cycle (Figure 3). As an aside, the only alternative $\mathrm{N}_{2}$-fixation pathway uses

$212 \mathrm{R} 12084)$, compared with $16 \mathrm{ATP}$ and $8 \mathrm{Fd}_{\text {red }}$ for the more common iron-molybdenum-cobalt nitrogenase

213 (KEGG reaction R05185). 
Not unexpectedly, the order of efficiency of amino acid synthesis efficiency is approximately the same as the order of efficiency of butanol synthesis. As before ${ }^{4}$, the $4 \mathrm{HB}$ cycle, which performed least well for butanol synthesis ${ }^{4}$, also performed least well for amino acid synthesis. Likewise, the Wood-Ljungdahl pathway performed the best (Figure 3A).

218 With increasing efficiency comes decreasing electricity cost (Figure 3B). The average cost of producing a gram of amino acid with $\mathrm{H}_{2}-4 \mathrm{HB}$ is $84.3_{-6.8}^{+0.9} \mathrm{kJg}^{-1}$ and $63.7_{-5.4}^{+0.7} \mathrm{kJg}^{-1}$ with $\mathrm{H}_{2}-\mathrm{WL}$ (costs of 0.07 and 0.05 to $70.9_{-9.1}^{2.8} \mathrm{kJg}^{-1}$ (costs of 0.08 and $0.06 \varnothing \mathrm{g}^{-1}$ ).

\section{Electromicrobial Protein is an energy-efficient alternative to current protein production technologies}

How do the upper-limit efficiencies predicted for EMP protein production compare with real world production efficiencies and energy costs? Most rigorous estimates of the total cradle-to-farm gate energy costs needed to produce a gram of beef, chicken, pork, eggs, and dairy ${ }^{48}$; soybeans ${ }^{49}$; insects ${ }^{50}$ and cultured meat ${ }^{14}$ consider only primary energy inputs. Estimates of primary energy input start at $44 \mathrm{~kJ} \mathrm{~g}^{-1}$ for soybeans ${ }^{49}$ and go up to $273 \mathrm{~kJ} \mathrm{~g}^{-1}$ for beef ${ }^{48}$ (Table S4).

However, traditional estimates of energy input into protein production are not suitable for an apples-toapples comparison to the numbers calculated in this article. These estimates consider the energy content of feed stocks such as grain and milk; and infrastructural costs such as transportation to the farm gate and tilling land. In the case of soy bean production, the estimates do not include the energy delivered by sunlight to the system to initially fix $\mathrm{CO}_{2}, \mathrm{~N}_{2}$ and synthesize amino acids. Likewise, for livestock and dairy production, they do not include the energy content of the sunlight needed to produce the feed, only its final energy content.

236 Traditional energy input estimates of protein production are not wrong. Quite rightly, sunlight has been 237 thought of as free of cost and global warming concerns. Furthermore, traditional analyses rightly concern themselves with necessary fossil energy inputs. However, as global agricultural production expands, the land for agriculture becomes an increasingly precious commodity. As a result, efficiency of use of sunlight becomes increasingly important.

Likewise, our analysis explicitly ignores infrastructural costs. While we would like to think that bioreactor production of protein could avoid many of these costs, simply thinking this does not make it so. We cannot say so with any certainty if the infrastructure energy costs, such as stirring, heating, gas exchange, are less

244 than the energy inputs associated with agriculture or livestock farming needed to produce a gram of protein.

245 Estimates of photosynthetic cost of producing protein are the closest comparison point to our work. The 246 closest comparison point to this work is a recent comparison of year round production of protein rich crops, 247 and their protein content with an empirical model of electromicrobial production methods by Leger et al. ${ }^{5}$. 248 The analysis by Leger et al. allows for calculation of the solar energy costs of photosynthetic production 249 (Table S5). Energy costs range from $47 \mathrm{MJ} \mathrm{g}^{-1}\left(\eta_{\mathrm{SP}}=0.035 \%\right)$ for soybeans grown in the US to $408 \mathrm{MJ} \mathrm{g}^{-}$ $250{ }^{1}\left(\eta_{\mathrm{SP}}=0.004 \%\right)$ for maize grown in India (Table S5).

251 In contrast, Leger et al. ${ }^{5}$ estimate an averaged sunlight to protein production efficiency of between $0.29 \%$ 252 (minimum food production efficiency) and $0.87 \%$ (maximum feed production efficiency) using a solar PV 
driven Methanol-RUMP pathway. These results presented here suggest that these efficiencies, at least instantaneously could be pushed almost an order of magnitude higher.

\section{Conclusion}

In this work, we examined a fundamental, molecular-scale model of electromicrobial production of amino acids. It is important to re-state here that this calculation does not predict the performance of any naturallyoccurring organism. It simply considers a set of redox transformations and enzymatic reactions, and predicts an upper limit efficiency for any natural or synthetic organism using these reactions.

Electromicrobial protein production could address many issues surrounding modern protein production including greenhouse gas emissions ${ }^{14,51,52}$, nitrogen run-off, and land use ${ }^{13,14,20,53,54}$. Recent results by Leger et al. ${ }^{5}$ suggest that the solar to protein conversion efficiency of agriculture could be improved by an order of magnitude by combining PV with electromicrobial production technologies.

We examined electromicrobial protein production systems that assimilate $\mathrm{N}_{2}$ using a FeMo nitrogenase reaction; assimilate carbon using one of the six known natural $\mathrm{CO}_{2}$-fixation pathways $(3 \mathrm{HP} / 4 \mathrm{HB}$, rTCA, $\mathrm{WL}, 4 \mathrm{HB}, \mathrm{CBB}, 3 \mathrm{HP}$ ) pathways or assimilate formic acid with the artificial formolase pathway; and uptake electrons and energy through $\mathrm{H}_{2}$-oxidation or extracellular electron uptake. The costs of $\mathrm{N}_{2}$-fixation mean that electromicrobial protein production is likely never to be as efficient as carbohydrate electromicrobial production. But, our results suggest that they could approach it.

The least efficient system (EEU coupled with the 4HB cycle; EEU-4HB) required $97.3_{-15.3}^{+3.3} \mathrm{kJg}^{-1}$ of an average amino acid (Figure 3B) (corresponds to an electrical to protein energy conversion efficiency, $\eta_{E P}=17.6_{-2.4}^{+0.6} \%$; Figure 3A). The most efficient system $\left(\mathrm{H}_{2}-\mathrm{WL}\right)$ required only $63.7_{-5.4}^{+0.7} \mathrm{kJg}^{-1}$ of amino acids (Figure 3B) $\left(\eta_{E P}=26.9_{-2.1}^{+0.3} \%\right.$, Figure 3A). If supplied with electricity by a perfectly efficient single junction Si PV the EEU-4HB system would produce protein with an efficiency of $\eta_{S P}=5.8 \%$, while the $\mathrm{H}_{2}$-WL system would produce protein with an efficiency of $\eta_{S P}=8.9 \%$. These results suggest that the process proposed by Leger et al. ${ }^{5}$ could be improved, at least instantaneously, by another order of 278 magnitude.

What's the best way to achieve the potential of electromicrobial protein production? All of the systems considered in this study rely upon the presence of at least a small amount ( $\geq$ a few hundred ppm) $\mathrm{O}_{2}$ to generate the maximum amount of reducing equivalents from incoming electrons $\mathrm{s}^{25,30,32}$. Natural options exist for carbon assimilation in high efficiency engineered EMP systems. For carbon assimilation, the Calvin cycle, $3 \mathrm{HP}$ cycle, and Formolase pathway can all be operated in the presence of $\mathrm{O}_{2}$. In fact, the $\mathrm{H}_{2}$-oxidizing microbe Ralstonia eutropha (the chassis organism for the Bionic Leaf which uses the Calvin cycle) fixes $\mathrm{CO}_{2}$ in the presence of at least $1 \% \mathrm{O}_{2}$, while the Fe-oxidizing microbe Sideroxydans lithotrophicus ES-1 uses EEU to power $\mathrm{CO}_{2}$ fixation in a micro-aerobic environment. production. Over the past decade, several groups have incorporated genes for $\mathrm{N}_{2}$-fixation into E. coli and demonstrated functional $\mathrm{N}_{2}$-fixation ${ }^{55-60}$. But, despite tantalizing possibilities ${ }^{61}$, all known nitrogenase enzymes are sensitive to $\mathrm{O}_{2}$. This creates a fundamental incompatibility between EEU and $\mathrm{N}_{2}$-fixation that needs to be solved. 
292 Creation of an $\mathrm{O}_{2}$-tolerant nitrogenase may be a tall order for evolution. Unlike other enzymes useful in 293 sustainable energy applications like the hydrogenase ${ }^{62}$, there are plenty of evolutionary pressures to drive 294 the creation of an $\mathrm{O}_{2}$-tolerant nitrogenase. Despite plenty of demand and opportunities for an $\mathrm{O}_{2}$-tolerant 295 nitrogenase to emerge, nature has not presented one.

296 To date, nature has solved the problem of operating the nitrogenase in an $\mathrm{O}_{2}$-rich environment by 297 sequestering it. For example, root nodules in leguminous plants provide an $\mathrm{O}_{2}$-shielded environment for 298 symbiotic $\mathrm{N}_{2}$-fixing microbes. Likewise filamentous $\mathrm{N}_{2}$-fixing cyanobacteria are able to operate the 299 nitrogenase enzyme inside $\mathrm{O}_{2}$-impermeable differentiated cells called heterocysts while simultaneously 300 operating oxygenic photosynthesis to generate reducing equivalents in adjacent cells ${ }^{63}$. A similar approach, 301 or recent advances in compartmentalization in synthetic biology ${ }^{64-68}$, give a menu of options for building a 302 synthetic $\mathrm{O}_{2}$-resistant compartment for the nitrogenase. Achieving this goal is likely to represent a major 303 challenge in synthetic biology.

304 Development of an $\mathrm{O}_{2}$-resistant compartment will also enable the implementation of highly efficient $\mathrm{CO}_{2}$ 305 fixation pathways like the 3HP/4HB cycle, rTCA cycle and Wood-Ljungdahl pathway in synthetic 306 organisms that simultaneously use $\mathrm{O}_{2}$ as a metabolic terminal electron acceptor.

307 Failure to operate enzymatic $\mathrm{N}_{2}$-fixation does not spell the end of the road for electromicrobial protein 308 production however. Much as there has been significant development of electrochemical $\mathrm{CO}_{2}$ reduction to $309 \mathrm{C}_{1}$ compounds, recent developments in electrochemical $\mathrm{N}_{2}$ reduction to ammonia could be a promising 310 complement to biological production of complex amino acids ${ }^{54}$. 


\section{End Notes}

\section{Code Availability}

314 All code used in calculations in this article is available at https://github.com/barstowlab/electrofoods and is

315 archived on Zenodo at https://doi.org/doi:10.5281/zenodo.5698500.

\section{Materials \& Correspondence}

317 Correspondence and material requests should be addressed to B.B.

\section{Author Contributions}

319 Conceptualization, L.W. and B.B.; Methodology, B.B; Investigation, L.W., S.M., K.R., J.S., M.H., E.N., 320 and B.B; Writing - Original Draft, L.W., S.M., K.R., and B.B.; Writing - Review and Editing, L.W. and 321 B.B.; Resources, B.B.; Supervision, B.B.;

\section{Acknowledgements}

323 We thank S. Alcaine in the Food Science Department at Cornell University for guidance. This work was 324 supported by Cornell University startup funds (to B.B.), a Burroughs-Wellcome Career Award at the 325 Scientific Interface (to B.B.), and US Department of Energy Biological and Environmental Research award 326 DE-SC0020179. K.R. was supported by a McNair graduate fellowship.

\section{Competing Interests}

328 The authors declare no competing interests. 


\section{$331 \quad$ Figures}

A. In vivo $\mathrm{CO}_{2}-$ and $\mathrm{N}_{2}$-fixation Electromicrobial
Production

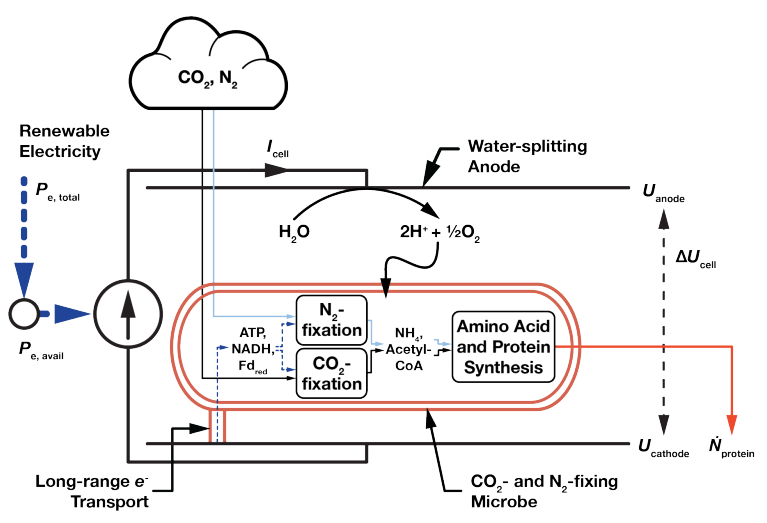

C. Long Range e- Transport Mechanisms

1. $\mathrm{H}_{2}$ Transport and Oxidation

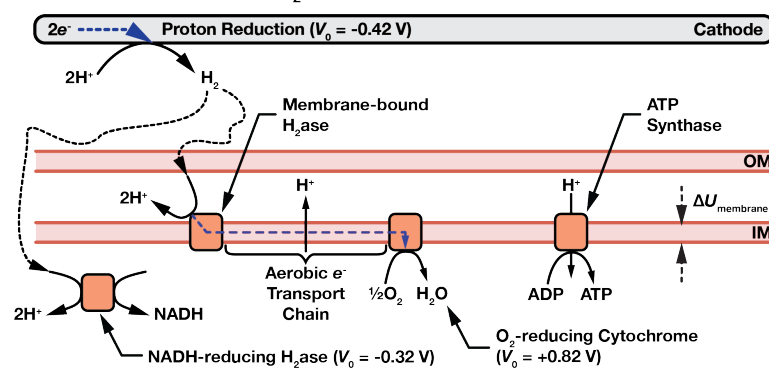

2. Extracellular $e^{-}$Uptake

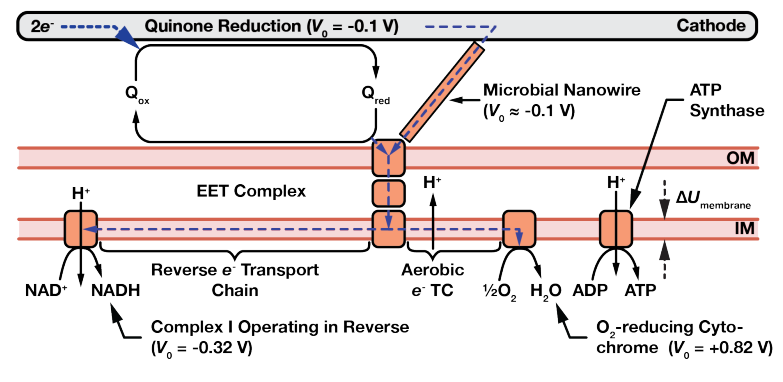

B. Electrochemical $\mathrm{CO}_{2}$-reduction and in vivo $\mathrm{N}_{2}$-fixation Electromicrobial Production

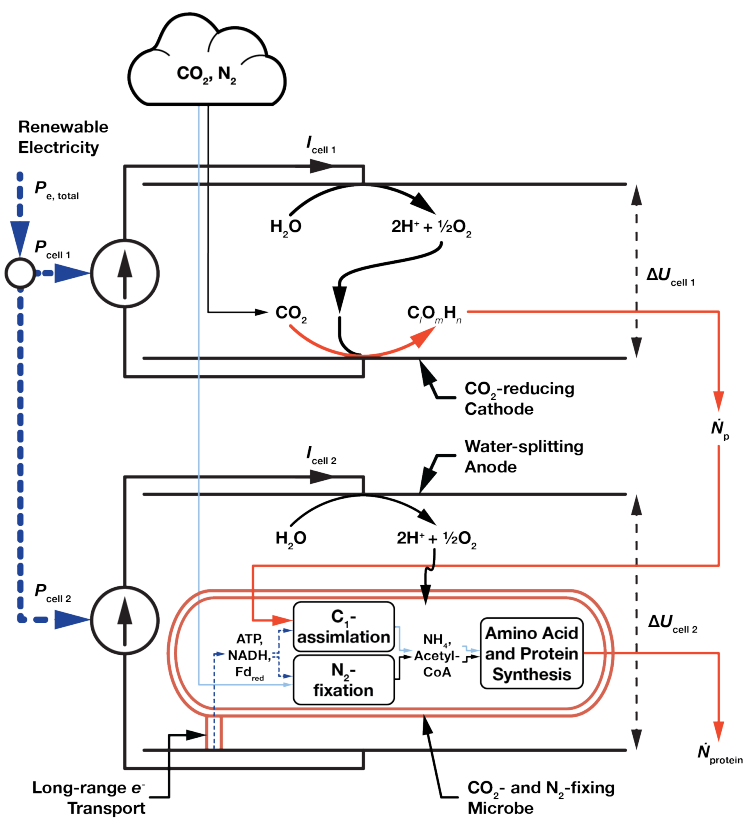

Figure 1. Schematic of amino acid electromicrobial production systems. (A) Single bio-electrochemical cell system where electricity is used to power in vivo $\mathrm{CO}_{2}$ - and $\mathrm{N}_{2}$-fixation. (B) Dual electrochemical cell system where $\mathrm{CO}_{2}$ is reduced in the first cell, and then assimilated in the second cell, and combined with enzymatically fixed $\mathrm{N}_{2}$. (C) Long range $e^{-}$transfer mechanisms considered in this article. In the first, $\mathrm{H}_{2}$ is electrochemically reduced on a cathode, transferred to the microbe by diffusion or stirring, and is enzymatically oxidized. In the second mechanism, extracellular electron uptake (EEU), $e^{-}$are transferred along a microbial nanowire (part of a conductive biofilm), or by a reduced medium potential redox shuttle like a quinone or flavin, and are received at the cell surface by the extracellular electron transfer (EET) complex. From the thermodynamic perspective considered in this article, these mechanisms are equivalent. 
bioRxiv preprint doi: https://doi.org/10.1101/2021.11.22.469619; this version posted November 22, 2021. The copyright holder for this preprint (which was not certified by peer review) is the author/funder, who has granted bioRxiv a license to display the preprint in perpetuity. It is made available under aCC-BY 4.0 International license.

Wise et al., Thermodynamic Constraints on Electromicrobial Protein Production

342 Electrons are then transported to the inner membrane where reverse electron transport is used to regenerate $343 \mathrm{NAD}(\mathrm{P}) \mathrm{H}$, reduced Ferredoxin (not shown), and $\mathrm{ATP}^{25,32}$. 

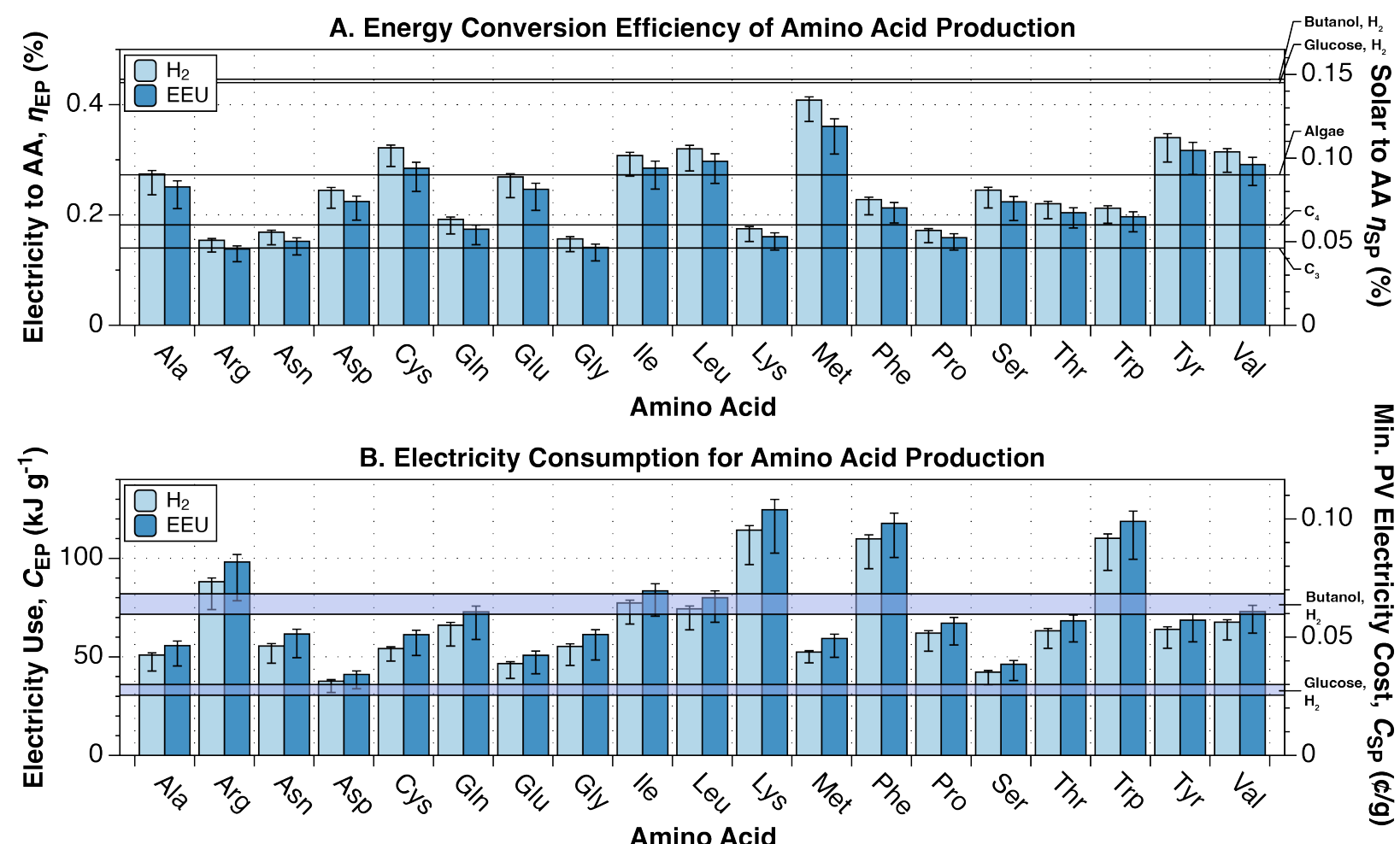

Figure 2. Energy conversion efficiency and energy cost of amino acid production. The upper limit energy conversion efficiency and minimum energy cost of amino acid production from $\mathrm{CO}_{2}, \mathrm{~N}_{2}$ and electricity by electromicrobial production systems using the Calvin cycle for $\mathrm{CO}_{2}$-fixation and either $\mathrm{H}_{2}$-oxidation or extracellular electron uptake (EEU) were calculated for 19 dietary amino acids (all except histidine) with the ELECTROFOODS package ${ }^{43}$. NADH, $\mathrm{Fd}_{\mathrm{red}}$, and $\mathrm{ATP}$ requirements for synthesis of each amino acid are tabulated in Dataset S2. This plot can be reproduced using the FIG-CBB_N2_TO_AMINO_ACIDS.PY program in the ELECTROFOODS package ${ }^{43}$.

(A) Upper limit electrical and solar energy conversion efficiency for amino acids. The left axis shows the electricity to amino acid energy conversion efficiency, while the right axis shows the solar to amino acid conversion efficiency, assuming the system is supplied by a perfectly efficient single-junction Si solar photovoltaic (solar to electrical efficiency of $32.9 \%$ (ref. ${ }^{69}$ )). As a first point of comparison, the upper limit solar to biomass energy conversion efficiencies of $\mathrm{C}_{3}, \mathrm{C}_{4}$ (refs. ${ }^{44,45}$ ), and algal photosynthesis ${ }^{46}$ are marked on the right axis. As a second point of comparison, we have also marked the projected upper limit solar to butanol $^{4}$ and glucose (calculated here) conversion efficiencies by an electromicrobial production system using $\mathrm{H}_{2}$-oxidation and the Calvin cycle.

(B) Minimum electrical and solar energy costs for the production of a gram of amino acids. The left axis shows the minimum electricity cost, while the right axis shows the minimum cost of that solar electricity, assuming that the US Department of Energy's cost target of $3 \notin$ per kWh by 2030 can be achieved ${ }^{47}$. 


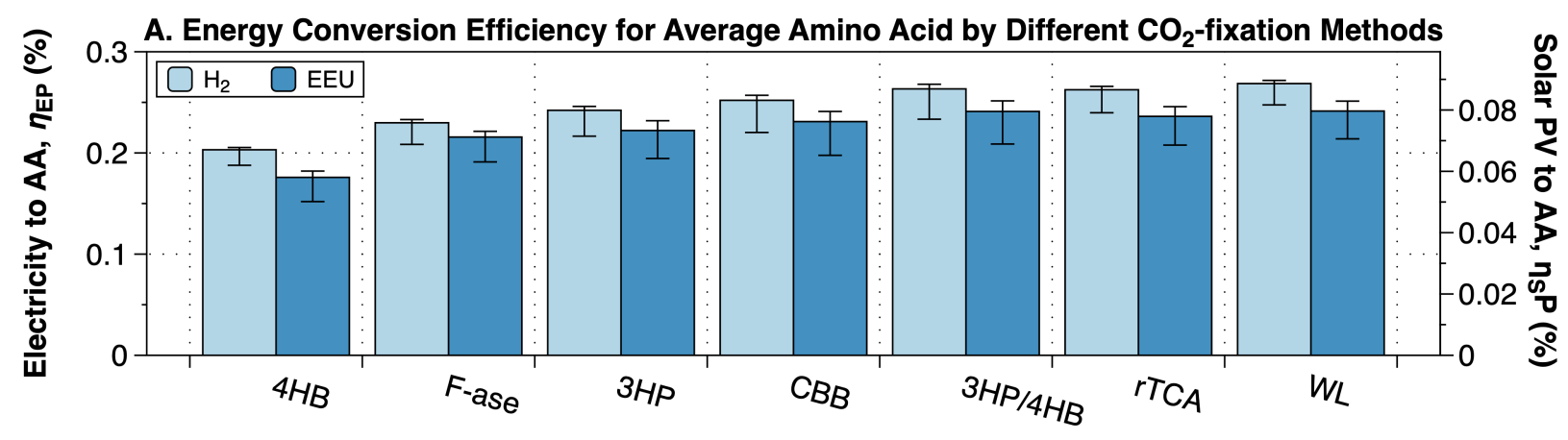

$\mathrm{CO}_{2}$-fixation or $\mathrm{C}_{1}$-assimilation Method

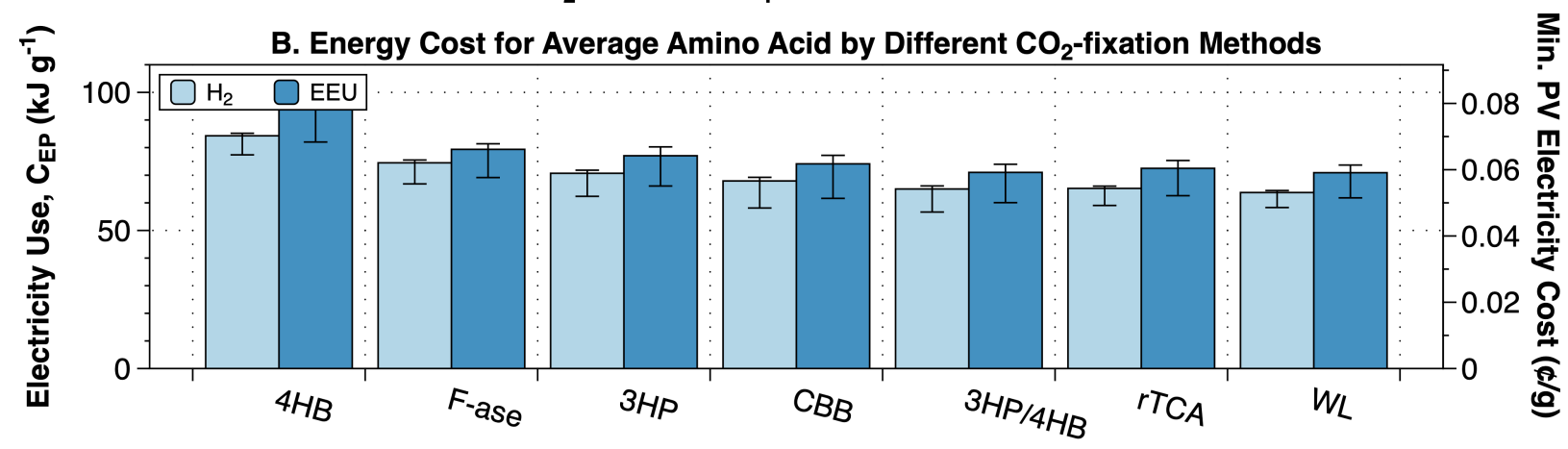

$\mathrm{CO}_{2}$-fixation or $\mathrm{C}_{1}$-assimilation Method

Figure 3. Changing $\mathrm{CO}_{2}$-fixation method can improve the performance of amino acid synthesis. The upper limit energy conversion efficiency and minimum energy cost of production of an average amino acid from $\mathrm{CO}_{2}$ or $\mathrm{HCOO}^{-}, \mathrm{N}_{2}$ and electricity by electromicrobial production systems using either $\mathrm{H}_{2}$-oxidation or extracellular electron uptake (EEU) and one of the 6 naturally-occurring $\mathrm{CO}_{2}$-fixation pathways or the synthetic Formolase formate assimilation pathway were calculated with the ELECTROFOODS package ${ }^{43}$. $\mathrm{NADH}, \mathrm{Fd}_{\mathrm{red}}$, and ATP requirements for synthesis of an average amino acid are tabulated in Dataset $\mathbf{S 2}$. This plot can be reproduced using the FIG-CBB_N2_TO_AMINO_ACIDS.PY program in the ELECTROFOODS package ${ }^{43}$. 3HP: 3-hydroxypropionate cycle; 3HP-4HB: 3-hydroxypropionate/4-hydroxybutyate cycle; 4HB: 4-hydroxybutyate cycle; CBB: Calvin-Bensson-Bassham cycle; Form: Formolase pathway; rTCA: reductive TCA cycle; WL: Wood-Ljungdahl pathway.

374 (A) Upper limit electrical and solar energy conversion efficiency for an average amino acid. The left axis shows the electricity to amino acid energy conversion efficiency, while the right axis shows the solar to amino acid conversion efficiency, assuming the system is supplied by a perfectly efficient single-junction Si solar photovoltaic (solar to electrical efficiency of $32.9 \%{ }^{69}$ ).

(B) Minimum electrical and solar energy costs for the production of a gram of an average amino acid. The left axis shows the minimum electricity cost, while the right axis shows the minimum cost of that solar electricity, assuming that the US Department of Energy's cost target of $3 \notin$ per kWh by 2030 can be 381 achieved $^{47}$. 
bioRxiv preprint doi: https://doi.org/10.1101/2021.11.22.469619; this version posted November 22, 2021. The copyright holder for this preprint (which was not certified by peer review) is the author/funder, who has granted bioRxiv a license to display the preprint in perpetuity. It is made available under aCC-BY 4.0 International license.

Wise et al., Thermodynamic Constraints on Electromicrobial Protein Production

\begin{tabular}{|c|c|c|c|c|c|}
\hline Parameter & Symbol & 1. $\mathrm{H}_{2}$ & 2. EEU & $\begin{array}{l}\text { 3. } \mathrm{H}_{2} \text { with } \\
\text { Formate }\end{array}$ & $\begin{array}{l}\text { 4. EEU with } \\
\text { Formate }\end{array}$ \\
\hline \multicolumn{6}{|l|}{ Electrochemical Cell Parameters } \\
\hline Input solar power (W) & $P_{\gamma}$ & 1,000 & 1,000 & 1,000 & 1,000 \\
\hline Total available electrical power (W) & $P_{\mathrm{e}, \text { total }}$ & 330 & 330 & 330 & 330 \\
\hline $\mathrm{CO}_{2}$-fixation method & & \multicolumn{2}{|c|}{ Enzymatic } & \multicolumn{2}{|c|}{ Electrochemical } \\
\hline Electrode to microbe mediator & & $\mathrm{H}_{2}$ & EEU & $\mathrm{H}_{2}$ & EEU \\
\hline Cell 1 cathode std. potential (V) & $U_{\text {cell } 1, \text { cathode, } 0}$ & \multicolumn{2}{|l|}{ N/A } & \multicolumn{2}{|c|}{0.82 [Torella2015a] } \\
\hline Cell 1 cathode bias voltage (V) & $U_{\text {cell 1, cathode, bias }}$ & \multicolumn{2}{|l|}{ N/A } & \multicolumn{2}{|c|}{$0.47[$ Liu2016a] } \\
\hline Cell 1 anode std. potential (V) & $U_{\text {cell } 1, \text { anode, } 0}$ & \multicolumn{2}{|l|}{ N/A } & \multicolumn{2}{|c|}{$\begin{array}{l}-0.43[\text { Y ishai2017a, } \\
\text { Zhang2018a] }\end{array}$} \\
\hline Cell 1 anode bias voltage (V) & $U_{\text {cell 1, anode, bias }}$ & \multicolumn{2}{|l|}{ N/A } & \multicolumn{2}{|c|}{1.3 [White2014a] } \\
\hline Cell 1 voltage $(\mathrm{V})$ & $\Delta U_{\text {cell } 1}$ & \multicolumn{2}{|l|}{ N/A } & \multicolumn{2}{|c|}{3.02} \\
\hline Cell 1 Faradaic efficiency & $\xi_{\mathrm{I} 1}$ & \multicolumn{2}{|l|}{ N/A } & \multicolumn{2}{|c|}{0.8 [Rasul2019a] } \\
\hline Carbons per primary fixation product & $v_{\mathrm{Cr}}$ & \multicolumn{2}{|l|}{ N/A } & \multicolumn{2}{|r|}{1} \\
\hline$e^{-}$per primary fixation product & $v_{\mathrm{er}}$ & \multicolumn{2}{|l|}{ N/A } & \multicolumn{2}{|r|}{2} \\
\hline $\begin{array}{l}\text { Cell } 2 \text { (Bio-cell) anode std. potential } \\
\text { (V) }\end{array}$ & $U_{\text {cell 2, anode, } 0}$ & $-0.41[$ Torella2015a] & $\begin{array}{c}-0.1 \\
\text { [Bird2011a, } \\
\text { Firer- } \\
\text { Sherwood2008 } \\
\text { a] }\end{array}$ & -0.41 & -0.1 \\
\hline Bio-cell anode bias voltage (V) & $U_{\text {cell 2, anode, bias }}$ & $0.3[$ Liu2016a] & $\begin{array}{c}0.2 \\
\text { [Ueki2018a] }\end{array}$ & 0.3 & 0.2 \\
\hline Bio-cell cathode std. potential (V) & $U_{\text {cell } 2, \text { cathode, } 0}$ & \multicolumn{4}{|c|}{0.82} \\
\hline Bio-cell cathode bias voltage (V) & $U_{\text {cell 2, cathode, bias }}$ & \multicolumn{4}{|c|}{0.47} \\
\hline Bio-cell voltage $(\mathrm{V})$ & $\Delta U_{\text {cell } 2}$ & $2[$ Liu2016a] & 1.59 & 2 & 1.59 \\
\hline Bio-cell Faradaic efficiency & $\xi_{12}$ & \multicolumn{4}{|c|}{1.0} \\
\hline \multicolumn{6}{|l|}{ Cellular Electron Transport Parameters } \\
\hline Membrane potential difference $(\mathrm{mV})$ & $\Delta U_{\text {membrane }}$ & \multicolumn{2}{|l|}{140} & \multicolumn{2}{|r|}{140} \\
\hline Terminal e- acceptor potential (V) & $U_{\text {Acceptor }}$ & \multicolumn{4}{|c|}{0.82} \\
\hline Quinone potential (V) & $U_{\mathrm{Q}}$ & \multicolumn{2}{|c|}{$-0.0885[\mathrm{Bird} 2011 \mathrm{a}]$} & \multicolumn{2}{|c|}{$-0.0885[\operatorname{Bird} 2011 \mathrm{a}]$} \\
\hline Mtr EET complex potential (V) & $U_{\mathrm{Mtr}}$ & $\mathrm{N} / \mathrm{A}$ & $\begin{array}{c}-0.1 \\
\text { [Salimijazi202 } \\
0 \mathrm{~b}]\end{array}$ & N/A & $\begin{array}{c}-0.1 \\
{[\text { Salimijazi2020b] }}\end{array}$ \\
\hline No. protons pumped per $e^{-}$ & $p_{\text {out }}$ & \multicolumn{2}{|c|}{ Unlimited } & \multicolumn{2}{|c|}{ Unlimited } \\
\hline \multicolumn{6}{|l|}{ Product Synthesis Parameters } \\
\hline No. ATPs for product synthesis & $v_{\mathrm{p}, \mathrm{ATP}}$ & & See Datas & $\mathbf{S 2}$ & \\
\hline No. NAD(P)H for product & $v_{\mathrm{p}, \mathrm{NADH}}$ & & See Datas & S2 & \\
\hline No. $\mathrm{Fd}_{\text {red }}$ for product & $v_{\mathrm{p}, \mathrm{Fd}}$ & & See Datas & S2 & \\
\hline Product energy density $\left(\mathrm{J}\right.$ molecule $\left.{ }^{-1}\right)$ & $E_{\text {protein }}$ & & See Tabl & $\mathbf{S 2}$ & \\
\hline
\end{tabular}

384 Table 1. Electromicrobial protein production model parameters. Model parameters used in this article are 385 based upon model parameters used in a previous analysis of the electromicrobial production of the biofuel 386 butanol $^{4}$. A sensitivity analysis was performed for all key parameters in this work ${ }^{4}$. 
bioRxiv preprint doi: https://doi.org/10.1101/2021.11.22.469619; this version posted November 22, 2021. The copyright holder for this preprint (which was not certified by peer review) is the author/funder, who has granted bioRxiv a license to display the preprint in perpetuity. It is made available under aCC-BY 4.0 International license.

Wise et al., Thermodynamic Constraints on Electromicrobial Protein Production

388

389 


\section{Bibliography}

3911 Porritt, J. \& McCarthy, M. The Global Protein Challenge. (Stockholm Resilience Centre, Stockholm, Sweden, 2017).

2 Claassens, N. J., Cotton, C. A. R., Kopljar, D. \& Bar-Even, A. Making quantitative sense of electromicrobial production. Nature Catalysis 2, 437-447, doi:10.1038/s41929-019-0272-0 (2019). Salimijazi, F., Parra, E. \& Barstow, B. Electrical Energy Storage with Engineered Biological Systems. Journal of Biological Engineering 13, 1-21, doi:10.1186/s13036-019-0162-7 (2019).

4 Salimijazi, F. et al. Constraints on the Efficiency of Engineered Electromicrobial Production. Joule 4, 2101-2130, doi:10.1016/j.joule.2020.08.010(2020).

5 Leger, D. et al. Photovoltaic-driven microbial protein production can use land and sunlight more efficiently than conventional crops. Proceedings of the National Academy of Sciences 118, e2015025118, doi:10.1073/pnas.2015025118 (2021). McClements, D. J. Future Foods, How Modern Science Is Transforming the Way We Eat. (2019). González, A. D., Frostell, B. \& Carlsson-Kanyama, A. Protein efficiency per unit energy and per unit greenhouse gas emissions: Potential contribution of diet choices to climate change mitigation. Food Policy 36, 562-570, doi:10.1016/j.foodpol.2011.07.003 (2011).

8 Heinke, J. et al. Water Use in Global Livestock Production-Opportunities and Constraints for Increasing Water Productivity. Water Resour Res 56, doi:10.1029/2019wr026995 (2020).

9 Ghosh, S., Suri, D. \& Uauy, R. Assessment of protein adequacy in developing countries: quality matters. Brit J Nutr 108, S77-S87, doi:10.1017/s0007114512002577 (2011). Prosekov, A. Y. \& Ivanova, S. A. Food security: The challenge of the present. Geoforum 91, 7377, doi:10.1016/j.geoforum.2018.02.030 (2018).

11 Tilman, D., Balzer, C., Hill, J. \& Befort, B. L. Global food demand and the sustainable intensification of agriculture. Proceedings of the National Academy of Sciences 108, 20260-20264, doi:10.1073/pnas.1116437108 (2011).

12 Hawksworth, J. \& Chan, D. The World in 2050: Will the shift in global economic power continue? , (PricewaterhouseCoopers, 2015).

13 Audsley, E. et al. Food, land and greenhouse gases. The effect of changes in UK food consumption on land requirements and greenhouse gas emissions., (The Committee on Climate Change, 2010).

14 Tuomisto, H. L. \& Mattos, M. J. T. d. Environmental Impacts of Cultured Meat Production. Environmental Science \& Technology 45, 6117-6123, doi:10.1021/es200130u (2011).

15 Voegele, J. \& Nelson, J. 4 priorities in the race to build a sustainable global food system. (2019).

16 Slade, R., Bauen, A. \& Gross, R. Global bioenergy resources. Nature Climate Change 4, 99-105, doi:10.1038/nclimate2097 (2014).

17 Poore, J. \& Nemecek, T. Reducing food's environmental impacts through producers and consumers. Science 360, 987-992, doi:10.1126/science.aaq0216 (2018).

18 Ritala, A., Häkkinen, S. T., Toivari, M. \& Wiebe, M. G. Single Cell Protein-State-of-the-Art, Industrial Landscape and Patents 2001-2016. Frontiers in Microbiology 8, 2009, doi:10.3389/fmicb.2017.02009 (2017).

19 Sillman, J. et al. Bacterial protein for food and feed generated via renewable energy and direct air capture of CO2: Can it reduce land and water use? Global Food Secur 22, 25-32, doi:10.1016/j.gfs.2019.09.007 (2019).

20 Mishra, A., Ntihuga, J. N., Molitor, B. \& Angenent, L. T. Power-to-Protein: Carbon Fixation with Renewable Electric Power to Feed the World. Joule 4, 1142-1147, doi:10.1016/j.joule.2020.04.008 (2020).

21 Gleizer, S., Bar-On, Y. M., Ben-Nissan, R. \& Milo, R. Engineering Microbes to Produce Fuel, Commodities, and Food from $\mathrm{CO}_{2}$. Cell Reports Phys Sci 1, 100223, doi:10.1016/j.xcrp.2020.100223 (2020). 


\section{2}

$\mathrm{Hu}, \mathrm{X}$. et al. Microbial Protein out of Thin Air: Fixation of Nitrogen Gas by an Autotrophic Hydrogen-Oxidizing Bacterial Enrichment. Environmental Science \& Technology 54, 3609-3617, doi:10.1021/acs.est.9b06755 (2020).

23 Nyyssölä, A. et al. Production of Endotoxin-Free Microbial Biomass for Food Applications by Gas Fermentation of Gram-Positive $\mathrm{H}_{2}$-Oxidizing Bacteria. ACS Food Science \& Technology 1, 470479, doi:10.1021/acsfoodscitech.0c00129 (2021).

24 Tubb, C. \& Seba, T. Rethinking Food and Agriculture 2020-2030: The Second Domestication of Plants and Animals, the Disruption of the Cow, and the Collapse of Industrial Livestock Farming. Industrial Biotechnology 17, 57-72, doi:10.1089/ind.2021.29240.ctu (2021).

25 Rowe, A. R. et al. Identification of a Pathway for Electron Uptake in Shewanella oneidensis. Communications Biology 4, 957, doi:10.1038/s42003-021-02454-x (2021).

26 Liu, C., Colón, B. C., Ziesack, M., Silver, P. A. \& Nocera, D. G. Water splitting biosynthetic system with $\mathrm{CO}_{2}$ reduction efficiencies exceeding photosynthesis. Science 352, 1210-1213, doi:10.1126/science.aaf5039 (2016).

27 White, J. L., Herb, J. T., Kaczur, J. J., Majsztrik, P. W. \& Bocarsly, A. B. Photons to formate: Efficient electrochemical solar energy conversion via reduction of carbon dioxide. Journal of $\mathrm{CO}_{2}$ Utilization 7, 1-5, doi:10.1016/j.jcou.2014.05.002 (2014).

28 White, J. L. et al. Light-Driven Heterogeneous Reduction of Carbon Dioxide: Photocatalysts and Photoelectrodes. Chemical Reviews 115, 12888--12935, doi:10.1021/acs.chemrev.5b00370 (2015).

29 Appel, A. M. et al. Frontiers, Opportunities, and Challenges in Biochemical and Chemical Catalysis of $\mathrm{CO}_{2}$ Fixation. Chemical Reviews 113, 6621-6658, doi:10.1021/cr300463y (2013).

30 Torella, J. P. et al. Efficient solar-to-fuels production from a hybrid microbial-water-splitting catalyst system. Proceedings of the National Academy of Sciences 112, 2337-2342, doi:10.1073/pnas.1503606112 (2015).

31 Milo, R., Jorgensen, P., Moran, U., Weber, G. \& Springer, M. BioNumbers - the database of key numbers in molecular and cell biology. Nucleic Acids Research 38, D750-D753, doi:10.1093/nar/gkp889 (2010).

32 Rowe, A. R. et al. Tracking electron uptake from a cathode into Shewanella cells: Implications for energy acquisition from solid-substrate electron donors. mBio 9, 1-19, doi:10.1128/mBio.0220317 (2018).

33 Kanehisa, M. \& Goto, S. KEGG: Kyoto Encyclopedia of Genes and Genomes. Nucleic Acids Research 28, 27-30, doi:10.1093/nar/28.1.27 (2000).

34 Kanehisa, M. Toward understanding the origin and evolution of cellular organisms. Protein Science 28, 1947-1951, doi:10.1002/pro.3715 (2019).

35 Kanehisa, M., Furumichi, M., Sato, Y., Ishiguro-Watanabe, M. \& Tanabe, M. KEGG: integrating viruses and cellular organisms. Nucleic Acids Research 49, gkaa970, doi:10.1093/nar/gkaa970 (2020).

36 Berg, J. M., Tymoczko, J. L. \& Stryer, L. Biochemistry. 5th edn, (W H Freeman, 2002).

37 Alissandratos, A. \& Easton, C. J. Biocatalysis for the application of $\mathrm{CO}_{2}$ as a chemical feedstock. Beilstein Journal of Organic Chemistry 11, 2370-2387, doi:10.3762/bjoc.11.259 (2015).

38 Claassens, N. J., Sousa, D. Z., dos Santos, V. A. P. M., de Vos, W. M. \& van der Oost, J. Harnessing the power of microbial autotrophy. Nature Reviews Microbiology 14, 692-706, doi:10.1038/nrmicro.2016.130 (2016).

39 Berg, I. A., Kockelkorn, D., Buckel, W. \& Fuchs, G. A 3-Hydroxypropionate/4-Hydroxybutyrate Autotrophic Carbon Dioxide Assimilation Pathway in Archaea. Science 318, 1782-1786, doi:10.1126/science.1149976 (2007).

40 Zarzycki, J., Brecht, V., Müller, M. \& Fuchs, G. Identifying the missing steps of the autotrophic 3hydroxypropionate $\mathrm{CO}_{2}$ fixation cycle in Chloroflexus aurantiacus. Proceedings of the National Academy of Sciences of the United States of America 106, 21317-21322, doi:10.1073/pnas.0908356106 (2009). 
488

489

490

491

492

493

494

495

496

497

498

499

500

501

502

503

504

505

506

507

508

509

510

511

512

513

514

515

516

517

518

519

520

521

522

523

524

525

526

527

528

529

530

531

532

53359

534

535

536
41

Huber, H. et al. A dicarboxylate/4-hydroxybutyrate autotrophic carbon assimilation cycle in the hyperthermophilic Archaeum Ignicoccus hospitalis. Proceedings of the National Academy of Sciences 105, 7851-7856, doi:10.1073/pnas.0801043105 (2008).

42 Siegel, J. B. et al. Computational protein design enables a novel one-carbon assimilation pathway. Proceedings of the National Academy of Sciences 112, 3704-3709, doi:10.1073/pnas.1500545112 (2015).

43 Barstow, B. Electrofoods. doi:10.5281/zenodo.5698500 (2021).

44 Zhu, X.-G., Long, S. P. \& Ort, D. R. What is the maximum efficiency with which photosynthesis can convert solar energy into biomass? Current Opinion in Biotechnology 19, 153-159, doi:10.1016/j.copbio.2008.02.004 (2008).

45 Zhu, X.-G., Long, S. P. \& Ort, D. R. Improving Photosynthetic Efficiency for Greater Yield. Annual Review of Plant Biology 61, 235-261, doi:10.1146/annurev-arplant-042809-112206 (2010).

46 Wijffels, R. H. \& Barbosa, M. J. An Outlook on Microalgal Biofuels. Science 329, 796-799, doi:10.1126/science.1189003 (2010).

47 SunShot 2030. (US Department of Energy, 2016).

48 Williams, A. G., Audsley, E. \& Sandars, D. L. Determining the environmental burdens and resource use in the production of agricultural and horticultural commodities. Defra project report IS0205. (Cranfield University and Defra, 2006).

49 Pimentel, D. Energy Inputs in Food Crop Production in Developing and Developed Nations. Energies 2, 1-24, doi:10.3390/en20100001 (2009).

50 Van Huis, A. et al. Edible insects: Future prospects for food and feed security. (Food and Agricultural Organization, 2013).

51 Garnett, T. Three perspectives on sustainable food security: efficiency, demand restraint, food system transformation. What role for life cycle assessment? Journal of Cleaner Production 73, 1018, doi:10.1016/j.jclepro.2013.07.045 (2014).

52 Smetana, S., Mathys, A., Knoch, A. \& Heinz, V. Meat alternatives: life cycle assessment of most known meat substitutes. Int J Life Cycle Assess 20, 1254-1267, doi:10.1007/s11367-015-0931-6 (2015).

53 Carpenter, S. R. Eutrophication of aquatic ecosystems: Bistability and soil phosphorus. Proceedings of the National Academy of Sciences 102, 10002-10005, doi:10.1073/pnas.0503959102 (2005).

54 Guo, W., Zhang, K., Liang, Z., Zou, R. \& Xu, Q. Electrochemical nitrogen fixation and utilization: theories, advanced catalyst materials and system design. Chem Soc Rev 48, 5658-5716, doi:10.1039/c9cs00159j (2019).

55 Temme, K., Zhao, D. \& Voigt, C. A. Refactoring the nitrogen fixation gene cluster from Klebsiella oxytoca. Proceedings of the National Academy of Sciences 109, 7085-7090, doi:10.1073/pnas.1120788109 (2012).

56 Wang, L. et al. A Minimal Nitrogen Fixation Gene Cluster from Paenibacillus sp. WLY78 Enables Expression of Active Nitrogenase in Escherichia coli. Plos Genet 9, e1003865, doi:10.1371/journal.pgen.1003865 PMID - 24146630 (2013).

57 Li, X.-X., Liu, Q., Liu, X.-M., Shi, H.-W. \& Chen, S.-F. Using synthetic biology to increase nitrogenase activity. Microbial Cell Factories 15, 43, doi:10.1186/s12934-016-0442-6 (2016).

58 Yang, Z. et al. Global investigation of an engineered nitrogen-fixing Escherichia coli strain reveals regulatory coupling between host and heterologous nitrogen-fixation genes. Scientific Reports $\mathbf{8}$, 10928, doi:10.1038/s41598-018-29204-0 (2018).

59 Li, Q. \& Chen, S. Transfer of Nitrogen Fixation (nif) Genes to Non-diazotrophic Hosts. ChemBioChem 21, 1717-1722, doi:10.1002/cbic.201900784 (2020).

60 Ryu, M.-H. et al. Control of nitrogen fixation in bacteria that associate with cereals. Nature Microbiology 5, 314-330, doi:10.1038/s41564-019-0631-2 (2020). 
61 MacKellar, D. et al. Streptomyces thermoautotrophicus does not fix nitrogen. Scientific Reports 6, 20086, doi:10.1038/srep20086 (2016).

62 Barstow, B. et al. A synthetic system links FeFe-hydrogenases to essential E. coli sulfur metabolism. Journal of Biological Engineering 5, 7, doi:10.1186/1754-1611-5-7 (2011).

63 Bothe, H., Schmitz, O., Yates, M. G. \& Newton, W. E. Nitrogen Fixation and Hydrogen Metabolism in Cyanobacteria. Microbiology and Molecular Biology Reviews 74, 529-551, doi:10.1128/mmbr.00033-10 (2010).

64 Chen, A. H. \& Silver, P. A. Designing biological compartmentalization. Trends Cell Biol 22, 662670, doi:10.1016/j.tcb.2012.07.002 (2012).

65 Chen, A. H., Robinson-Mosher, A., Savage, D. F., Silver, P. A. \& Polka, J. K. The Bacterial Carbon-Fixing Organelle Is Formed by Shell Envelopment of Preassembled Cargo. PLoS ONE 8, e76127, doi:10.1371/journal.pone.0076127 (2013). Encapsulated Cargo. ACS Synthetic Biology 5, 303-311, doi:10.1021/acssynbio.5b00237 (2016). genome. Nature 552, 415, doi:10.1038/nature25157 (2017).

68 Flamholz, A. I. et al. Functional reconstitution of a bacterial $\mathrm{CO}_{2}$ concentrating mechanism in $E$. coli. Elife 9, e59882, doi:10.7554/elife.59882 (2020).

555

69 Nelson, J. The Physics of Solar Cells. (Imperial College Press, 2003). 